\title{
A LEED Environmental Performance Certificate Application in Terms of Recyclable Content
}

\author{
Goksel Demir, Ummugulsum Alyuz, Eser Okten, and Hanefi Ozgoren
}

\begin{abstract}
Sustainable construction technologies, which are necessary for sustainable environment are important to minimize environmental impacts of urbanization and for the maximum efficiency of the structure. For this purpose, construction of sustainable/green buildings is a growing trend in Turkey and the world. Solid waste management at green buildings is one of the important parameters for sustainability of the building.

In this study, solid waste management in green buildings and the potential use of waste as construction material are investigated within the context of one of the most used certificates in Turkey; LEED NC 2009 environmental performance certificate. First of all, literature about how to use industrial value of the waste as construction material is reviewed and then two buildings which were entitled to get 'gold' category LEED NC 2009 certificate and a building which was not applied for any green building certificate are evaluated in terms of calculation practices. The results show that, usage of waste as a construction material is applicable with little effort in green buildings.
\end{abstract}

Index Terms-Green building, LEED NC 2009, solid waste, waste recycling.

\section{INTRODUCTION}

Construction and construction materials industries, with their increased rate of current activity in Turkey, had the most significant effect on environment and climate change. Construction industry was involved in natural resources consumption, greenhouse gas emissions due to high fuel and electricity consumption, production of construction waste due to construction and demolition activities [1]. Therefore, green building construction was rapidly gaining importance in order to ensure sustainability of construction industry. Green building was a structure, which had minimal adverse effects on environment, and was constructed with the concepts of eco-architecture, energy efficiency, and comfort.

Thus sustainable management of wastes emerged as a requirement, tackling all wastes being generated during the life cycle of any building. Green building standards on sustainable management of wastes were based on a grading system and they were used to evaluate the sustainability performance of buildings in terms of ecology, energy, and environment.

Green building certificates categorized wastes in two

Manuscript received October 24, 2012; revised February 6, 2013.

G. Demir, U. Alyuz, and E. Okten are with the Bahcesehir University Environmental Engineering Department, Besiktas Istanbul, Turkey (e-mail: goksel.demir@bahcesehir.edu.tr, ummugulsum.alyuz@bahcesehir.edu.tr, eser.okten@bahcesehir.edu.tr).

H. Ozgoren is with the Istanbul Metropolitan Municipality (e-mail: hanefi.ozgoren@ibb.gov.tr) classes. First of the classes included waste generated during construction, use and after use of the building. The second class was comprised of the recycled/re-used building materials and elements, which could be directly used as building materials during construction phase. Thus two goals would be served by reusing waste and facilitating sustainable buildings.

The most common waste types that were used as construction material were concrete, asphalt, wood, aluminum, and iron. Old concrete as a result of destruction of buildings could be reused as filler material at concrete constructions and as pavement support at road constructions. Also certain components of construction wastes such as aluminum and iron could be recycled and used as raw material in manufacturing new construction materials [2].

Wastes that were generated by other industries might also be utilized by integrating them into manufacturing of building components. Wood chip waste and waste from production of lime brick production could be used in brick production [3]. Due to low unit weight of waste tires, they could be used as filling material in embankments, retaining walls and the ground fills [4]. Marble pieces and powdered marble waste could be used as raw material in the production of cement, lime, calcined dolomite, slag making materials and plaster material [5], as chemical additive for the improvement of uneven ground features [6], as aggregate for concrete and ground plate, and as filling material in compressed road and rail floors, dams and other constructions. Thermoplastic PVC waste was used in the production of building materials such as concrete [7]. Fly ash from large combustion plants had a positive effect on solidification properties of cement and concrete [8]. Using silica fume, which was used in production of silicon metal or ferrosilicon alloys, increased strength of concrete and reduced its permeability [9]. Silica fume also reduced water / cement ratio in cement and helped to obtain impermeable internal structure in concrete [10]. At the same time, there were further studies for the conversion of incised old asphalt to new asphalt by specific technologies [11] for the usage in the road constructions and usage of boron production related wastes in the construction sector [12].

First of the most widely used environmental performance evaluation certificates was BREEAM (Building Research Establishment Environmental Assessment Method), which was introduced in 1990 in England by Building Research Establishment. Then, LEED (USA), SBTool (International), EcoProfile (Norway), Promise (Finland), Green Mark for Buildings (Singapore), HK-BEAM and Cepas (Hong Kong), Green Star (Australia), SBAT (South Africa), CASBEE (Japan), Environmental Status (Sweden), and others 
followed.

Currently, there were numerous certification systems for different types of buildings. Generally LEED and BREEAM certificates have been applied in Turkey. However there was not a local certification system in Turkey yet, CEDBIK (Turkish Green Building Council) has been working on this issue [2].

The number of the buildings having LEED and BREEAM certificates regarding to their cities were given in Fig. 1.

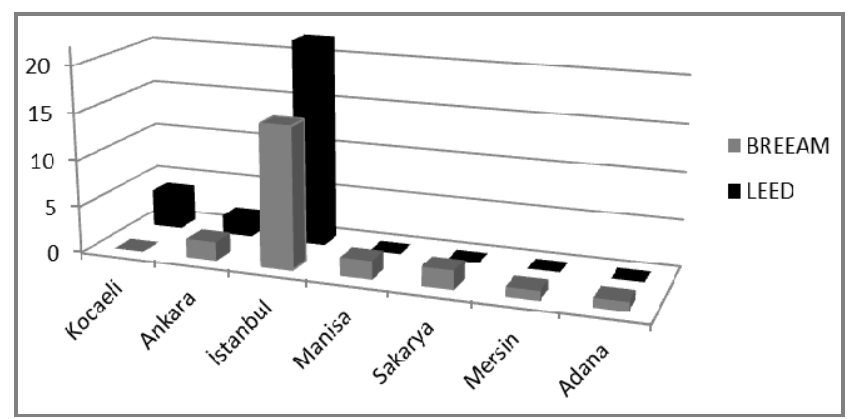

Fig. 1. LEED and BREEAM certified buildings in Turkey

Totally 52 buildings were certificated in Turkey and 28 of them had LEED Certificate. 22 of these LEED certified green buildings were located in Istanbul. Fig. 2 showed the distribution and numbers of each LEED certificate category in Turkey, such that 19 of the 28 LEED certified green buildings in Turkey had gold category certificate.

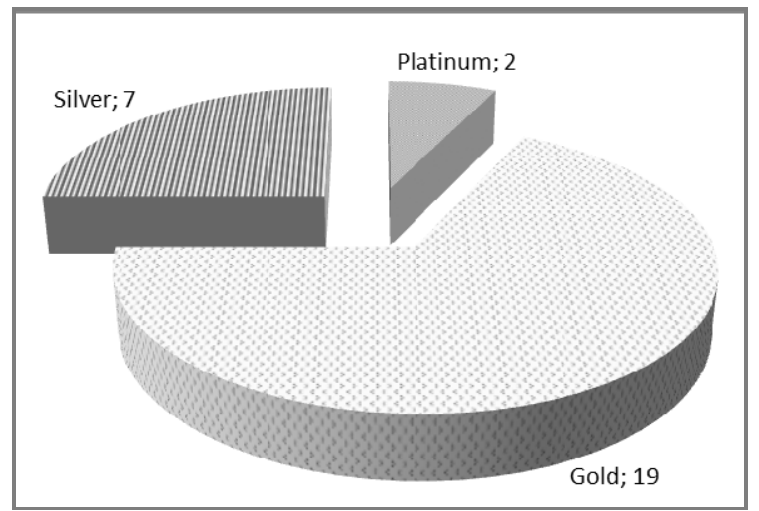

Fig. 2. Distribution and numbers of LEED certificate categories of the green buildings in Turkey

Also 15 of these "gold category" LEED certified buildings were located in Istanbul, 3 of them in Kocaeli and one of them in Ankara. In this study two gold category LEED certified buildings in Istanbul and Kocaeli were investigated in terms of LEED certificate application within the context of recyclable content.

\section{Green Building EnVironmental Performance CERTIFICATES - LEED NC 2009}

LEED (Leadership in Energy and Environmental Design) 2009 NC (New Construction) certification system was discussed within the context of integration of solid wastes to construction. Furthermore two buildings, which were entitled to get 'gold' category LEED NC 2009 certificate, and a control building, which did not go through any kind of green building certification, were evaluated.

\section{A. LEED 2009 NC Scoring System}

US Green Building Council (USGBC) was established in 1993 by architects, material manufacturers, owners, contractors, and environmental groups as a US-based volunteer organization. Since 1998 it provided LEED (Green Building) certification all over the world, especially in North America. Calculations were done in accordance with the American standards, except for the cases, where the applicant's national standards were higher than those of USA's. So far, USGBC certified more than 30,000 structures in 30 countries [13].

The highest possible score in LEED NC 2009 was 110. There were four certification levels: Classic Certificate (26-32 points), Silver Certificate (33-38 points), Gold Certificate (39-51 points), and Platinum Certificate (52-69 points). Summary of the grading system used for certification was given in Table I. Scores in credit weight column presented the significance of each category within all LEED categories.

TABLE I: GRADING SYSTEM FOR LEED 2009 NC CERTIFICATE CATEGORIES

\begin{tabular}{clcc}
\hline \hline No & Scoring category & Max Score & Credit Weight (\%) \\
\hline 1 & Sustainable Sites & 26 & 23,6 \\
2 & Water Efficiency & 10 & 9,1 \\
3 & Energy and Atmosphere & 35 & 31,9 \\
4 & Materials and Resources & 14 & 12,7 \\
5 & Indoor Environmental Quality & 15 & 13,6 \\
6 & Innovation \& Design Process & 6 & 5,5 \\
7 & Regional Priority Credits & 4 & 3,6 \\
\hline \hline
\end{tabular}

LEED 2009 NC 'Sustainable Sites' category in Table I was mainly related to factors such as choice of location, ease of access, percentage of open space, and light over-exposure. 'Water Efficiency' category entailed water use reduction, water efficient landscaping and innovative wastewater technologies. 'Energy and Atmosphere' category included effective energy performance optimization in the energy consuming processes such as water heating, residential heating, cooling, and management of emitted gases from these stages. 'Indoor Environmental Quality' category was about technical applications affecting quality of indoors such as aeration techniques in order to provide residents with an improved air quality, sufficient amount of daylight and prevent from exposure to cigarette smoke. 'Innovation and Design Process' category examined development of the project. 'Regional Priority' category aimed to consider geographical conditions for the selection of project location at the design stage. 'Materials and Resources' category was related with the solid waste management for the building and was mainly the subject of this study, covering $12.7 \%$ of all certification scores. Thus, if a construction project fulfilled all requirements of the 'Materials and Resources category," then it would get 14 points as the full score from this category only.

Criteria and scores in this category were given in Table II. Score for MRP1 credit was not provided because it was given 
as a pre-requisite for this category. Therefore, in order to receive a certificate, appropriate collection equipment and conditions for the collection of recyclable waste should be ensured in the building.

TABLE II: 'MATERIALS AND RESOURCES' CATEGORY CRITERIA IN LEED 2009 NC CERTIFICATE

\begin{tabular}{l|l|c|c}
\hline \hline Credit Code & Credit Title & Score & $\begin{array}{c}\text { Weight in } \\
\text { Total (\%) }\end{array}$ \\
\hline MRP1 & $\begin{array}{l}\text { Storage and Collection of } \\
\text { Recyclables } \\
\text { Building Reuse - Maintain Existing } \\
\text { Walls, Floors and Roof }\end{array}$ & 3 & - \\
prerequisite & $2,7 \%$ \\
MRcredit 1.2 & $\begin{array}{l}\text { Building Reuse - Maintain Interior } \\
\text { Nonstructural Elements }\end{array}$ & 1 & $0,9 \%$ \\
MRcredit 2 & Construction Waste Management & 2 & $1,8 \%$ \\
MRcredit 4 & Recycled Content & 2 & $1,8 \%$ \\
MRcredit 5 & Regional Materials & 2 & $1,8 \%$ \\
MRcredit 6 & Rapidly Renewable Materials & 2 & $1,8 \%$ \\
MRcredit 7 & Certified Wood & 1 & $0,9 \%$ \\
\hline & Total & 14 & $12.7 \%$ \\
\hline
\end{tabular}

MRcredit 1.1, entailed using external structure from existing old buildings instead of using new construction materials in order to reduce consumption of new resources. Thus, roofing, flooring, and structural elements from an old building would be used again [13]. If $95 \%, 75 \%$, and $55 \%$ re-use of old materials were sustained then 3 points, 2 points, and1 point would be earned, respectively.

The purpose of MRcredit 1.2 was to provide at least $50 \%$ reuse of doors, windows, and floorings from old buildings, in new buildings. $75 \%$ recycled or recovered construction waste from old building corresponded to 2 points, and $50 \%$ corresponded to 1 point.

Reusing non-hazardous construction waste and debris in order to prevent them from being transferred to landfill or incineration was the aim of MRcredit 2. MRcredit 3 aimed at using salvaged, refurbished or reused materials, the sum of which constituted at least $5 \%$ (1 point) or $10 \%$ ( 2 points) of total material value, based on cost of the total value of materials on project to reduce demand for new materials and to reduce waste.

The purpose of MRcredit 4 was the use of materials with recycled content (as defined in ISO 14021). If those recycled materials would account for $10 \%$ of the total value of the materials in the project, then that would bring 1 point, while $20 \%$ brought 2 points.

MRcredit 5 addressed selection of the local or regional construction materials. The main idea was to minimize adverse environmental effects of transportation. Materials, which accounted for $10 \%$ of the total cost and were provided within a 500-mile radius corresponded to 1 point, while $20 \%$ got 2 points.

MRcredit 6 aimed at increasing the use of rapidly renewable building materials and products. The target was set for $2.5 \%$ of the total value of all building materials. Rapidly renewable building materials and products were made from plants that were typically harvested within 10 -years or at a shorter cycle.
The purpose of the MRcredit 7 was to encourage use of a minimum $50 \%$ (based on cost) of wood-based materials and products that were certified in accordance with the Forest Stewardship Council's principles and criteria, for wood building components.

All of these credit scores were summed for each category, and then the certification type was decided for the corresponding construction project.

\section{B. LEED 2009 NC Application}

In this section, an office building and a factory building in Turkey, which got Gold LEED environmental performance certificates, were investigated in terms of their effects to the environment. Additionally, a construction project, which never applied for LEED Certification was investigated too, in order to evaluate the effect of certification decision on waste management in particular. In Table III, 'Materials and Resources" category of the LEED 2009 NC scores were summarized for both buildings.

TABLE III: “MATERIALS AND RESOURCES” CATEGORY CRITERIA SCORES OF THE TWO CONSTRUCTION PROJECTS

\begin{tabular}{|c|c|c|c|c|}
\hline \multirow{2}{*}{ Credit Code } & \multirow{2}{*}{ Credit Title } & \multirow{2}{*}{$\begin{array}{l}\text { Max } \\
\text { credit } \\
\text { score }\end{array}$} & \multicolumn{2}{|c|}{ Received Score } \\
\hline & & & $\begin{array}{c}\text { Factory } \\
\text { (Kocaeli) }\end{array}$ & $\begin{array}{c}\text { Office } \\
\text { (Istanbul) }\end{array}$ \\
\hline $\begin{array}{c}\text { MRP1 } \\
\text { (prerequisite) }\end{array}$ & $\begin{array}{l}\text { Storage and } \\
\text { Collection of } \\
\text { Recyclables }\end{array}$ & Prereq. & done & done \\
\hline MRcredit 1.1 & $\begin{array}{l}\text { Building Reuse - } \\
\text { Maintain Existing } \\
\text { Walls, Floors and } \\
\text { Roof }\end{array}$ & 3 & 0 & 0 \\
\hline MRcredit 1.2 & $\begin{array}{l}\text { Building Reuse - } \\
\text { Maintain Interior } \\
\text { Non-structural } \\
\text { Elements }\end{array}$ & 1 & 0 & 0 \\
\hline MRcredit 2 & $\begin{array}{l}\text { Construction Waste } \\
\text { Management }\end{array}$ & 2 & 2 & 2 \\
\hline MRcredit 3 & Materials Reuse & 2 & 0 & 0 \\
\hline MRcredit 4 & Recycled Content & 2 & 2 & 1 \\
\hline MRcredit 6 & Regional Materials & 1 & 0 & 0 \\
\hline MRcredit 7 & $\begin{array}{l}\text { Rapidly Renewable } \\
\text { Materials }\end{array}$ & 1 & 0 & 0 \\
\hline & Total & 12 & 4 & 3 \\
\hline
\end{tabular}

Factory in Kocaeli had a total of 4 points and office building in Istanbul had 3 points from the criteria of "Materials and Resources" category. Finally scores from each category were summed and a final score was achieved to be between 39 and 51. As a result these two projects were entitled to get "Gold" category LEED certificate.

Both buildings met the MRP1 criteria, which was on "Storage and Collection of Recyclables" and also was a pre-requisite. It was not assigned a score therefore the buildings did not get any score for this criteria. Furthermore, both buildings gained two full points from "Construction Waste Management" criteria.

The "Recycled Content" criterion, which was primarily related to the aim of this study, gained 2 points to factory in Kocaeli and 1 point to office building in Istanbul. Detailed calculations for these buildings were given in Table IV, which included ratios of the recycled materials used in buildings, and their effect on certificate score. 
TABLE IV: "MRCREDIT 4 - RECYCLABLE CONTENT” CRITERIA CALCUlation For the Two EXAMPLE Buildings Which Were EnTITLED TO GET “LEED” CERTIFICATE IN “GOLD” GEVEL

\begin{tabular}{|c|c|c|c|}
\hline \multirow[b]{2}{*}{ FACTORY (Kocaeli) } & $\begin{array}{c}\text { A } \\
\text { Recycling } \\
\text { content } \\
\text { ratio } \\
\end{array}$ & $\begin{array}{c}\text { B } \\
\text { Recyclable } \\
\text { material } \\
\text { budget }(\$)\end{array}$ & $\begin{array}{c}\mathbf{A x B} \\
\text { Total budget } \\
\text { of recycled } \\
\text { content }(\$)\end{array}$ \\
\hline & & & \\
\hline Concrete & $15 \%$ & 634,548 & $95,182.20$ \\
\hline Concrete Iron - rebar & $98 \%$ & 739,112 & $724,329.76$ \\
\hline Structural Steel & $30 \%$ & 889,097 & $266,729.10$ \\
\hline Pumice Block (brick) & $20 \%$ & 143,567 & $28,713.40$ \\
\hline Aluminium Materials & $22 \%$ & 233,456 & $51,360.32$ \\
\hline \multicolumn{3}{|c|}{ Total recyclable material budget : } & $1,166,314.78$ \\
\hline \multicolumn{3}{|c|}{ Total construction material budget : } & $3,896,577.00$ \\
\hline \multicolumn{3}{|l|}{ Accounting Rate } & $29.93 \%$ \\
\hline \multicolumn{4}{|l|}{ OFFICE (Istanbul) } \\
\hline Concrete & $20 \%$ & 453,000 & 90,600 \\
\hline Rebar & $98 \%$ & 654,000 & 640,920 \\
\hline Aluminium Joinery & $28 \%$ & 334,587 & $93,684.36$ \\
\hline Sheet Metal Doors & $26 \%$ & 165,709 & $43,084.34$ \\
\hline Rock wool Suspended Ceiling & $28 \%$ & 102,487 & $28,696.36$ \\
\hline \multicolumn{3}{|c|}{ Total recyclable material budget : } & $896,985.06$ \\
\hline \multicolumn{3}{|c|}{ Total construction material budget : } & $4,760,100$ \\
\hline Accounting Rate & & & $18.84 \%$ \\
\hline
\end{tabular}

Recycling content ratio referred to the recycled percentage of used materials, and recyclable material budget referred to the budget used for recycled material supply. Accounting Ratio, which helped to determine the credit score, was obtained through dividing total budget of the recycled content by total construction material budget. As indicated in the credit description, this credit corresponded to 1 point for the ratio between $10-20 \%$ and 2 for $20 \%$ or more.

In the case of Kocaeli factory building, accounting rate of $29.93 \%$ brought 2 points to the factory. For the Istanbul office building case, the $18.84 \%$ accounting rate brought 1 point. In both cases, the largest contribution was provided by rebar, which had $98 \%$ recycling ratio.

Especially in recent years, regardless of certification, more materials with recycled content were being used in structures due to increasing environmental awareness, incentives and developing material technology. In order to test this hypothesis, a housing structure of 3-B class (has no fire resistance requirements except for exterior bearing walls) in Marmara region, which did not receive any certificate of environmental performance, was evaluated according to the LEED 2009 NC MRcredit 4. Accounting rate was calculated for that building and Table $\mathrm{V}$ was created by presenting the retrieved scores.

Recycling content ratio of the materials used in this project was of the average values for standard materials and was taken from the producers located in Marmara region. Furthermore, budgets of the materials used in the project were calculated by multiplying average unit consumption values, which were determined with the unit prices taken from the same producers.

According to Table V, even a regular building, which did not receive a certificate or did not claim to be ecological or green, could get 1 point from LEED $2009 \mathrm{NC}$ by using only a few essential building materials that were produced by current technology. If a previous version "LEED NC v 2.2" was considered to evaluate this building, it would have taken 2 full points from this criterion (it should not be ignored that "LEED-NC v 2.2" version was active until the first half of 2009).

TABLE V: "MRCREDIT 4 - RECYCLABLE CONTENT" CRITERION CALCULATION For A COMPLETED CONSTRUCTION PROJECT IN MARMARA

\begin{tabular}{|l|c|r|r|}
\multicolumn{1}{|c|}{ REGION. } \\
& $\begin{array}{c}\text { A } \\
\text { Recycling } \\
\text { content ratio }\end{array}$ & $\begin{array}{c}\text { B } \\
\text { Recyclable } \\
\text { material budget (\$) }\end{array}$ & $\begin{array}{c}\text { AxB } \\
\text { Total budget of } \\
\text { recycled content (\$) }\end{array}$ \\
\hline Concrete & $70 \%$ & $39.583,33$ & $2.770,83$ \\
Rebar & $98 \%$ & $38.333,33$ & $37.566,67$ \\
PVC Materials & $92 \%$ & $6.222,22$ & $5.724,44$ \\
\hline \multicolumn{4}{|c}{ Total recyclable material budget : } \\
& Total construction material budget : & $46.061,94$ \\
& \multicolumn{3}{c}{ Accounting Rate: } \\
\hline \hline
\end{tabular}

Considering the detailed calculations of a building (Table $\mathrm{V})$, rebar had the highest affect on accounting ratio (9.94\%) among the building materials, which were most widely used and had high recycling ratios. The main reason for the highest contribution of rebar was its acquisition from scrap material in Turkey, and all over the world as well. Therefore the level of recycled content was approximately 98\%. The other reason was that rebar could not be surpassed in terms of cost/benefit analysis with today's technology. Therefore use of rebar was required and had a large share in total cost of materials.

\section{CONCLUSION}

In this study, 7 criteria for earning points along with 1 pre-requisite, which reduced amount of wastes before, during, and after construction, were investigated in terms of their weighted averages within the context of LEED NC 2009 environmental performance certification system. 14 points out of 110 full score in the certificate $(12.7 \%$ of the total score of the certificate) came from solid waste management part of the "Materials and Resources" category. The recycled content criterion was assigned 2 points within the 14 points ( $1.18 \%$ of the total score of the certificate) in the "Materials and Resources" category.

The minimum score needed in order to get the "GOLD" level "LEED $2009 \mathrm{NC}$ " environmental performance certificate was 39. "Materials and Resources" category criterion had $12.7 \%$ share in LEED, and it corresponded to $30.7 \%$ when it was expressed on gold certification basis. Factory (Kocaeli) and office building (Istanbul) got 3.6\% and $2.7 \%$ in terms of LEED score from this category, respectively. When the Gold level was considered, the ratios were $10.2 \%$ for factory (Kocaeli) and $7.7 \%$ for office (Istanbul). casein conclusion, these buildings gained only a quarter of the maximum score from "Materials and Resources" category.

In regard with the calculations on a regular building in Turkey, which has not applied for any environmental performance certificate, it was clear that, earning 1 point from LEED 2009 NC was not a challenge. This was mainly 
due to increased rates of recycled content use in the current construction materials production sector. Thus, it could be considered as an incentive for the building owners, which were seeking to take LEED certification.

Consequently, the certification system was effective in terms of solid waste management but the effectiveness should be increased by developing scope and requirements for this category. Additionally the $1.8 \%$ current weight of the "recyclable content" criterion should be increased approximately up to $5 \%$. Thus the application of this easily facilitated and highly beneficial criterion would be encouraged.

\section{REFERENCES}

[1] Union of Chambers of Turkey, TOBB (2011). Appearance of the construction materials sector in Turkey Report.

[2] H. Ozgoren, "Evaluating Obtaining Building Materials from Wastes in The Way Of Sustainability \& an Environment Performance Certificate Application," M.Sc. thesis, Dept. of Urban Systems and Transportation Assessment, Bahcesehir Univ., Istanbul, Turkey, 2012.

[3] P. Turgut and H. M. Algin, "Limestone dust and wood sawdust as brick material," Building and Environment, vol. 42, pp. 3399-3403, 2007.

[4] T. Alatas, E. T. Somunkıran, and P. Ahmetzade, "Usage of eregli iron and steel factory slag as aggregate in asphalt concrete," Firat Univ. Science and Techn. Journal, vol. 18, no. 2, pp. 225-234, 2006.

[5] A. Sentürk, L. Gunduz, and I. Ugur, (1996). An environment approach - evaluation of marble wastes, The First Int. Symp. On Mine Environmental Engineering, 29-31 July, Kütahya, pp. 286-287.

[6] I. Zorluer and M. Usta, (2003). Improvement of grounds with marble powder waste. IVth Marble Symposium, Turkey, December 18-19.

[7] Y. W. Choi, D. Z. Moon, J. S. Chung, and S. K. Cho, "Effects of properties of concrete," Cem Concr. Res., vol. 35, pp. 776-781, 2005.

[8] E. Turhan, Concrete. Ankara: METU Publishing, 2003.

[9] R. Duval and E. H. Kadri, "Influence of silica fume on the workability and compressive strength of high performance concretes," Cement and Concrete Research, pp. 533-547, 1998

[10] H. Toutanji, N. Delatte, S. Aggoun, R. Duval, and A. Danson, "Effect of supplementary cementitious materials on the compressive strength and durability of short-term cured concrete," Cement and Concrete Research Journal, vol. 34, no. 2, pp. 311-319, 2004.

[11] H. Akbulut and C. Gürer, "Evaluation of waste marbles as aggregate on asphalt coatings," IMO Technical Journal, vol. 261, pp. 3943-3960, 2002.

[12] Booklet of 1st International Symposium on Boron, October 3 to 4, Dumlupinar University, Kütahya, 2002.

[13] LEED Steering Committee. (2009). LEED 2009 For New Construction and major renovations. [Online]. Available: https://new.usgbc.org/sites/default/files/LEED \%202009\%20Rating NC-GLOBAL_07-2012_8c.pdf

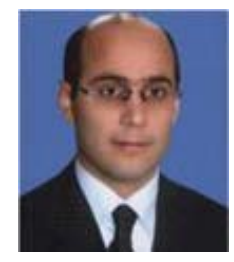

Goksel Demir was born in Agri, Turkey in 1970. He has Ph.D. degree in environmental engineering, Istanbul University in 2002. He has M.S. degree in Environmental engineering (1997) and B.S. degree in Biology in Istanbul University (1993). His research interests are Air Pollution and Control, Microbial Fuel cells and Sustainable Power Generation, Water Pollution and Control

$\mathrm{He}$ was assigned as a Research Assistant in Istanbul University, Department of Environmental Engineering in 1994, and Dr. Research Assistant in 2002 and Assistant Professor in 2004, Assistant Professor in Bahcesehir University Department of Environmental Engineering in 2006. Currently he has working as Associated Professor in Bahcesehir University Department of Environmental Engineering in Istanbul, Turkey since 2008. Dr. Demir is Adviser Board Member of "Journal of Laboratory World" and member of Mediterranean Scientific Association of Environmental Protection (MESAEP), International Solid Waste Association (ISWA) and American Association for the Advancement of Science (AAAS).

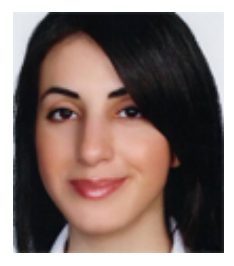

Ummugulsum Alyuz was born in Malatya, Turkey in 1984. She has MSc. degree in Environmental Engineering in Istanbul Technical University in 2012 and other master degree as MBA in Istanbul University in 2010 and B.S. degree in Environmental Engineering in Trakya University (2008). Currently she is a $\mathrm{PhD}$ candidate of Istanbul Technical University Eurasia Earth Systems Institute. Her research interests are Air Pollution and Control, Solid Waste Management.

She is assigned as a Research Assistant in Bahcesehir University, Istanbul Turkey, and Department of Environmental Engineering in 2012 and worked as an technical office engineer in Cevka Construction Co Ltd from 2008 to 2012 in the solid waste management sector.

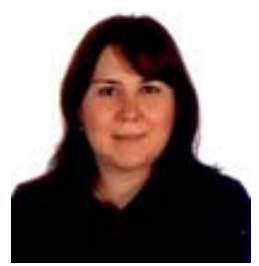

Hatice E. Okten was born in Istanbul, Turkey in 1980. She has Ph.D. degree in environmental engineering, University of Wisconsin-Madison in 2008. She has M.S. degree in Environmental Engineering (2002) and B.S. degree in Environmental Engineering in Istanbul University (1999). Her research interests are water and wastewater treatment.

She has assigned as Assistant Professor in Bahcesehir University, in Istanbul Turkey since 2008 and as Research Assistant in Istanbul Technical University between 2000 and 2002.

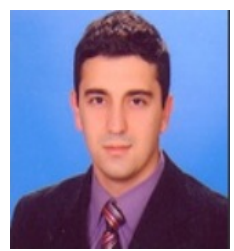

Hanefi Ozgoren was born in Istanbul, Turkey in 1980. He has MSc. degree in Urban Systems and Transportation Assessment Master Program in 2012 and BSc degree in Firat University Civil Engineering Department in 2002. Her research interests are environmental performance certificates in construction industries.

Municipality since 2008. 